\title{
Solo Mega Sinepleks Sebagai Wadah Apresiasi Perfilman Yang EDUKATIF DAN REKREATIF
}

\author{
Febriar Nilamsari, Hardiyati, M. Asrori \\ Program Studi Arsitektur \\ Universitas Sebelas Maret Surakarta \\ Email : febriar.nilam@gmail.com
}

\begin{abstract}
Film is one of the entertainment media that can be used as a medium of learning. Currently, film is developing in Indonesia, as well as in Surakarta. Many people, especially young people to appreciate the film. They watch movies and many are keen to make it. The aims of Solo Mega Sinepleks were to facilitate cinema activities that entertain and contains elements of education, including watching movies and filmmaking learning. The problem is how to realize interesting building, can incorporate elements of education and recreation, full filling cineplex and its supporting facility standard, and achieve the look of the building that could represent the function inside. The method is by processing of exterior appearance and layout inside the building to create a cineplex which facilitate educational activities with recreational design. Results obtained in the form of building design that is able to represent the function of the building as an educational film center with an attractive design and convenient for visitors.
\end{abstract}

Keywords: Cineplex, Educative, Film Appreciation, Recreational

\section{PENDAHULUAN}

Film adalah salah satu sarana hiburan yang mempunyai daya tarik tinggi di masyarakat, mulai dari kalangan dewasa hingga anak-anak. Selain sebagai sarana hiburan, film juga mempunyai fungsi sebagai sarana informasi dan pendidikan. Film dapat digunakan sebagai media pembelajaran. melalui film, pesan atau isi yang terkandung dalam film tersebut akan lebih mudah tersampaikan kepada para penikmatnya.

Banyak masyarakat, khususnya anak muda mengapresiasi film. Mereka tidak hanya menonton film, tetapi juga tertarik untuk membuatnya.

Film-film yang baik dihasilkan melalui proses pembuatan. Proses pembuatan film tersebut juga merupakan suatu proses pembelajaran. proses pembelajaran tersebut memerlukan suatu wadah.

Solo Mega Sinepleks sebagai salah satu wadah kegiatan perfilman yang edukatif dan rekreatif. Di dalamnya berisi kegiatan yang berhubungan dengan film. Mulai dari memberikan informasi, mempelajari proses pembuatan, menonton, dan mendiskusikan film.

Desain yang rekreatif adalah desain yang mampu menimbulkan suasana indah, santai / rileks, menghibur, dan menyenangkan. (Suardana, I Nyoman Gde. Bali Post. Minggu 28 Agustus 2005). Bangunan ini direncanakan dapat menggabungkan unsur edukasi dan rekreasi, memenuhi standar kelayakan fasilitas sinepleks, serta mewujudkan tampilan bangunan yang merepresentasikan fungsi di dalamnya dengan desain bangunan yang rekreatif. Dalam perancangan sinepleks yang terpenting adalah aspek struktur dan standar persyaratan ruang. Struktur harus dapat menunjang atap yang dengan bentang lebar karena ruang bioskop yang bebas kolom. Standar persyaratan bioskop juga harus diperhatikan sehingga dapat memberikan kenyamanan terhadap penonton.

Berdasarkan permasalahan tersebut, sinepleks ini diharapkan mampu mewujudkan bangunan yang sesuai fungsi, memenuhi standar kelayakan, dengan tetap menampilkan fisik bangunan yang menarik.

\section{METODE}

Untuk mendapatkan desain akhir berupa Solo Mega Sinepleks yang edukatif dan rekreatif, konsep desain rekreatif 
diaplikasikan pada poin-poin utama berikut ini:

\section{Konsep Ruang}

Desain rekreatif yang diterapkan yaitu penataan ruang dan sirkulasi. Konsep rekreatif diaplikasikan ke dalam penataan ruang untuk menciptakan suasana nyaman dan menarik yang sesuai fungsi ruang. Pada sirkulasi ditunjukkan melalui kemudahan, kenyamanan, dan nilai estetika. Sirkulasi di dalam bangunan memberi kejelasan dan kenyamanan dengan cara memisahkan jalur sirkulasi berdasarkan pelaku dan tujuan kegiatannya.

2. Bentuk dan Tampilan Bangunan

Desain rekreatif yang diterapkan pada bangunan adalah konsep bangunan yang menarik dari segi eksterior untuk menciptakan bangunan yang dapat merepresentasikan fungsi di dalamnya.

\section{ANALISIS}

\subsection{Analisis Peruangan}

Analisis kebutuhan ruang bertujuan untuk mengetahui jenis-jenis ruangan yang dibutuhkan oleh Solo Mega Sinepleks. Ruangan-ruangan ini (lihat Tabel 1) diperoleh melalui analisis pelaku beserta kegiatan di dalam sinepleks.

Tabel 1. Kebutuhan Ruang

\begin{tabular}{lll}
\hline Pelaku & Kegiatan & Peruangan \\
\hline Pengunjung & Datang & Hall \\
& Informasi & R. informasi \\
& Membaca & Perpustakaan \\
& literatur & \\
& Melihat & Museum mini \\
koleksi & \\
& Mengikuti & R. workshop \\
& workshop & \\
& Menonton & Studio bioskop \\
& film & \\
& Melakukan & R. diskusi \& \\
& diskusi \& & R. seminar \\
Seminar & \\
Sengelola & Bekerja & R. pengelola \\
& Bongkar muat & Loading Dock \\
Semua & barang & \\
Pelaku & Menitipkan & Parkir \\
\hline
\end{tabular}

\begin{tabular}{ll}
\hline Ibadah & Mushola \\
MCK & Toilet \\
\hline
\end{tabular}

\subsection{Analisis Tapak}

Tapak berada di Jalan L.U. Adisucipto, Kelurahan Jajar, Kecamatan Laweyan, dengan luas tapak $\pm 18.000 \mathrm{~m}^{2}$. Lokasi tapak strategis karena dekat dengan pusat kota, fasilitas umum serta prasarana transportasi lain. Memiliki utilitas dan infrastruktur yang memadai.

Orientasi tapak terekspos dari Jalan L.U. Adisucipto. Luasan tapak dapat menampung seluruh kebutuhan ruang yang direncanakan.

\subsection{Analisis Pencapaian}

Analisis pencapaian bertujuan untuk menentukan Main Entrance (ME) dan Side Entrance (SE) yang ideal.

Akses pencapaian kendaraan pengunjung menuju lokasi tapak adalah melalui Jalan L.U. Adisucipto dan Jalan Siwalan. Jalan L.U. Adisucipto merupakan Jalan raya selebar $\pm 12 \mathrm{~m}$ dan merupakan jalan utama, sedangkan Jalan Siwalan yang merupakan jalan lingkungan selebar $\pm 6 \mathrm{~m}$. Oleh karena itu letak ME direncanakan menghadap sisi utara ke arah Jalan L.U. Adisucipto dan SE direncanakan menghadap ke sisi timur ke arah Jalan Siwalan.

Letak pintu masuk dan keluar baik ME maupun SE direncanakan sejauh mungkin dari titik-titik kepadatan guna meminimalisir terjadinya kemacetan (lihat Gambar 1).

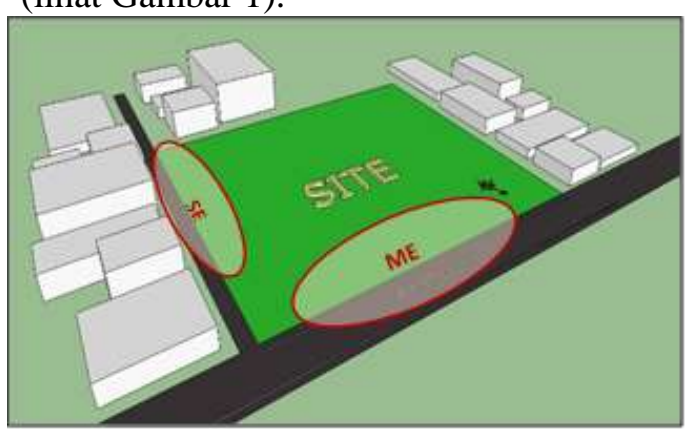

Gambar 1. Analisis Pencapaian

\subsection{Analisis Sirkulasi}

Bertujuan untuk mengatur jalannya sirkulasi di dalam tapak dan bangunan yang memberi kemudahan serta kenyamanan bagi pengguna sinepleks. 
Untuk menghindari keruwetan dalam tapak, maka sirkulasi ke luar dan masuk kendaraan dipisah. Side Entrance (SE) diletakkan terpisah dengan Main Entrance (ME) sebagai akses ke luar masuk kendaraan servis (lihat Gambar 2).

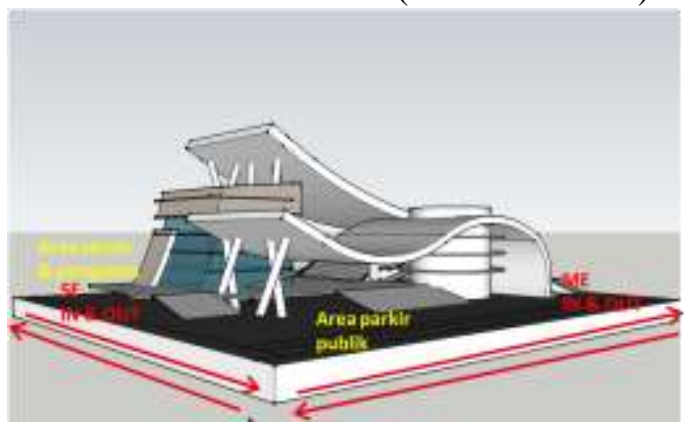

Gambar 2. Sirkulasi Di Dalam Tapak

\subsection{Analisis Klimatologi}

Angin di Indonesia rata-rata berhembus dari tenggara ke barat laut dan sebaliknya. Angin tenggara bersifat panas dan membawa polusi. Angin barat laut bersifat sejuk.

Matahari pagi dapat dimanfaatkan sebagai pencahayaan alami di dalam bangunan. Matahari sore yang panas dan silau dapat direduksi dengan meminimalisir bukaan pada sisi barat bangunan.

Berdasarkan analisis angin dan matahari, orientasi bangunan menghadap utara-selatan untuk mendapatkan penghawaan dan pencahayaan alami yang baik (lihat Gambar 3).

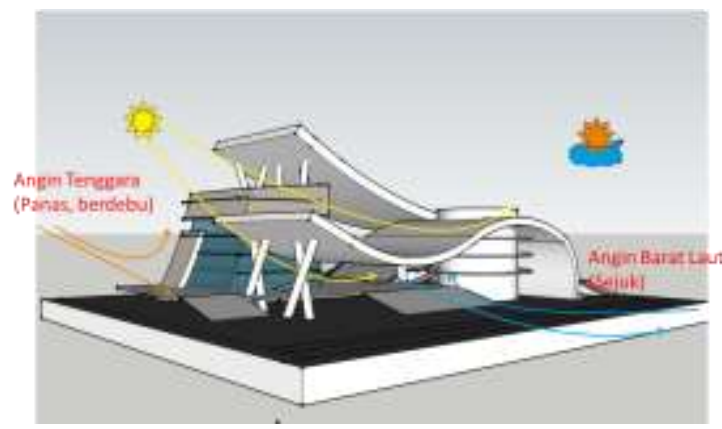

Gambar 3. Analisis Klimatologis

\subsection{Analisis Pemintakatan (Zoning)}

Pemintakatan berdasar pada beberapa pertimbangan. Bertujuan untuk menentukan mintakat (zoning) berdasarkan jenis kegiatan dan keadaan tapak. Dengan dasar pertimbangan arah matahari, kebisingan, jenis dan sifat kegiatan. Analisis arah matahari digunakan untuk menempatkan area yang membutuhkan cahaya matahari secara langsung atau tidak. Analisis kebisingan untuk menentukan area mana yang membutuhkan ketenangan dan terhindar dari kebisingan.

Berikut ini adalah tabel jenis dan sifat kegiatan.

Tabel 2. Jenis dan Sifat Kegiatan

\begin{tabular}{|c|c|}
\hline $\begin{array}{l}\text { Mintakat } \\
\text { (zoning) }\end{array}$ & Sifat Kegiatan \\
\hline $\begin{array}{l}\text { Zona } \\
\text { Kegiatan } \\
\text { Informasi }\end{array}$ & $\begin{array}{l}\text { Mudah } \\
\text { dijangkau. } \\
\text { - } \text { Dekat dengan } \\
\text { pencapaian } \\
\text { utama (ME). } \\
\text { - Mendapat } \\
\text { pencahayaan dan } \\
\text { penghawaan } \\
\text { alami yang baik. } \\
\text { - Memerlukan } \\
\text { ketenangan. } \\
\end{array}$ \\
\hline $\begin{array}{l}\text { Zona } \\
\text { Kegiatan } \\
\text { Pertunjukan }\end{array}$ & $\begin{array}{ll}\text { - } & \text { Bersifat umum. } \\
\text { - Memerlukan } \\
\text { ketenangan. }\end{array}$ \\
\hline $\begin{array}{l}\text { Zona } \\
\text { Kegiatan } \\
\text { Evaluasi }\end{array}$ & $\begin{array}{l}\text { - } \text { Bersifat umum. } \\
\text { - Memerlukan } \\
\text { ketenangan. }\end{array}$ \\
\hline $\begin{array}{l}\text { Zona } \\
\text { Kegiatan } \\
\text { Penunjang }\end{array}$ & $\begin{array}{ll}\text { - } & \text { Bersifat umum. } \\
\text { - } & \text { Tidak } \\
\text { memerlukan } \\
\text { ketenangan. }\end{array}$ \\
\hline $\begin{array}{l}\text { Zona } \\
\text { Kegiatan } \\
\text { Pengelolaan }\end{array}$ & $\begin{array}{l}\text { - } \text { Bersifat terbatas. } \\
\text { - Tidak dapat } \\
\text { diakses } \\
\text { pengunjung } \\
\text { secara bebas. }\end{array}$ \\
\hline $\begin{array}{l}\text { Zona } \\
\text { Kegiatan } \\
\text { Servis }\end{array}$ & $\begin{array}{ll}\text { - } & \text { Bersifat } \\
\text { pelayanan. } \\
\text { - } \text { Tidak } \\
\text { memerlukan } \\
\text { ketenangan } \\
\text { - Peletakan zona } \\
\text { ini berada di } \\
\text { bagian yang } \\
\text { tidak terlihat dari } \\
\text { pintu utama. } \\
\end{array}$ \\
\hline
\end{tabular}


Berdasarkan analisis di atas (lihat Tabel 2), diperoleh pemintakatan zona ruang sebagai berikut (lihat Gambar 4)

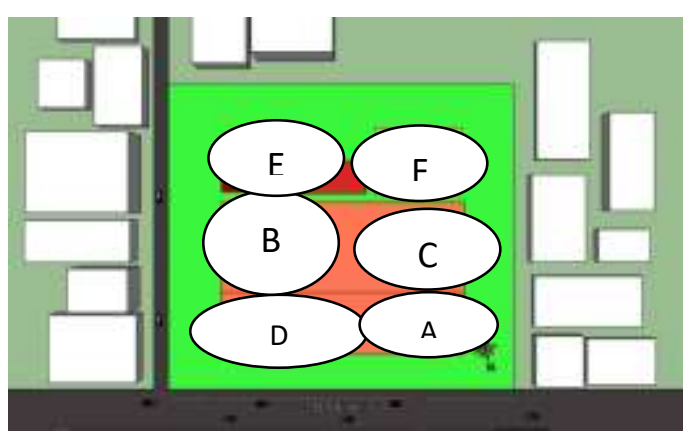

Keterangan:

A: Zona Kegiatan Informasi

B: Zona Kegiatan Pertunjukan

C: Zona Kegiatan Evaluasi

D: Zona Kegiatan Penunjang

E: Zona Kegiatan Pengelolaan

F: Zona Kegiatan Servis

Gambar 4. Pemintakan Ruang

\subsection{Analisis Konsep Ruang}

Ruang di dalam sinepleks dibagi menjadi beberapa kelompok yang memiliki kemiripan jenis dan sifat kegiatan. Ruang auditorium memiliki kemiripan fungsi dengan studio bioskop yang membutuhkan bentang lebar dan persyaratan akustik. Menurut Leslie L. Doelle dalam buku Akustik Lingkungan (1990), contoh bentuk denah yang sesuai dengan ruang auditorium dan bioskop yaitu (lihat Gambar 5)

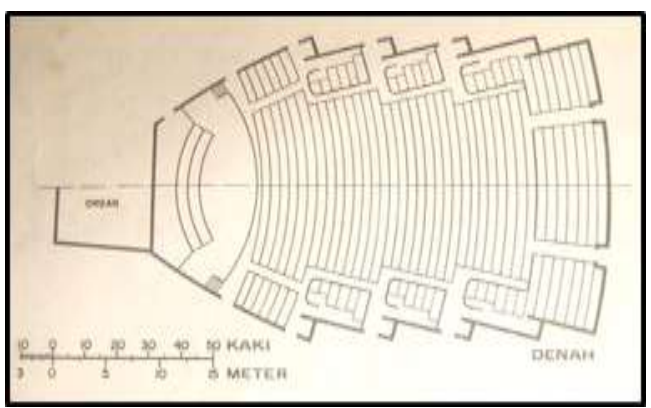

Gambar 5. Denah Berbentuk Kipas (sumber: Akustik Lingkungan)

Persyaratan ruang auditorium dan akustik antara lain:

- Denah berbentuk kipas membawa penonton lebih dekat ke sumber bunyi, sehingga memungkinkan konstruksi balkon. Bentuk ini paling cocok dengan kebutuhan akustik.

- Desain penataan lantai miring dengan sudut kemiringan minimal $30^{\circ}$.

- Bentuk dinding ruang dibuat tidak teratur, dipasang penyerap, pemantul suara, dan dikomposisikan secara silih berganti.

- Penyebaran bunyi dengan membuat bentuk langit-langit yang tidak teratur.

- Lebar kursi minimal $50 \mathrm{~cm}$, lebar jalan sirkulasi antar kursi depan dan belakang minimal $35 \mathrm{~cm}$, dan jarak antara kursi depan ke belakang 84$100 \mathrm{~cm}$.

- Sumber bunyi harus dikelilingi oleh permukaan pemantul bunyi.

- Susut pandang penonton pada kursi paling tepi di baris terdepan maksimal $30^{\circ}$.

\subsection{Analisis Bentuk dan Tampilan Bangunan}

\subsubsection{Analisis Bentuk Bangunan}

Bentuk bangunan mempertimbangkan sistem massa dan bermacam-macam gubahan massa, seperti: segiempat, segitiga, dan lingkaran. Hal ini berdasarkan beberapa pertimbangan yaitu:

1.Kesan yang ditampilkan.

2.Kemudahan pengaturan tata letak ruang.

3. Keamanan pengguna.

4. Kemudahan pengolahan sirkulasi.

5.Penyesuaian terhadap fisik di lingkungan tapak dan sekitar tapak.

6. Estetika bentuk.

Berdasarkan faktor pertimbangan di atas, terutama kemudahan dalam pengaturan tata letak ruang, maka bentuk dasar bangunan yang dianggap memenuhi kriteria di atas adalah bentuk persegi yang di dalamnya terdapat bentuk lingkaran sebagai variasi dan pengembangannya dengan massa tunggal. Pengembangan massa persegi dengan cara menambah atau mengurangi bentuk dasar.

\subsubsection{Analisis Tampilan Bangunan}

Solo Mega Sinepleks merupakan fasilitas yang digunakan oleh umum 
sehingga bangunan memiliki kepribadian terbuka. Kafetaria sebagai ruang komunal dan area penerima didesain terbuka tanpa dinding memberikan kesan terbuka. Pengaplikasian material kaca pada dinding luar juga dapat memberikan kesan bangunan yang terbuka bagi calon pengunjung.

Untuk menghasilkan tampilan bangunan yang mampu menampilkan fungsi bangunan sebagai sinepleks, fasad bangunan mengadaptasi elemen yang berhubungan dengan film. Hal ini diwujudkan dengan menggunakan desain atap dan ornamen bangunan yang melengkung menyerupai roll film dan sudut kemiringan atap yang terbuka menyerupai clapboard.

\subsection{Analisis Sistem Struktur}

1. Analisis Sub Structure

Sub structure mempertimbangkan beberapa jenis pondasi seperti: batu kali, footplate, sumuran, dan tiang pancang.

Berdasarkan pertimbangan tersebut jenis struktur yang akan digunakan adalah pondasi footplate.

2. Analisis Super Structure

Bangunan yang akan dirancang memiliki bentang kolom yang lebar. Dengan demikian sistem struktur yang dipilih adalah struktur rangka baja dengan modul jarak antar kolom delapan meter. Hal ini berdasarkan pertimbangan bahwa struktur baja memiliki karakteristik cukup ringan, fleksibel dalam pembagian ruang, mampu menahan gempa dan getaran, dengan bentangan cukup luas.

3. Analisis Upper Structure

Struktur atap yang digunakan adalah kombinasi struktur rangka baja dan space frame. Selain berfungsi sebagai penyalur beban, struktur tersebut juga berfungsi sebagai estetika.

\section{KESIMPULAN (KONSEP DESAIN)}

Dari hasil analisis serta hasil korelasi dari beberapa data di atas, maka diperoleh hasil berupa:

Nama

: Solo Mega Sinepleks

$$
\begin{array}{ll}
\text { Lokasi } & \text { : Jalan L.U. Adisucipto } \\
\text { Luas Lahan } & : \pm 18.000 \mathrm{~m}^{2} \\
\text { Luas Bangunan } & : \pm 12.500 \mathrm{~m}^{2} \\
\text { Konsep desain } & \text { yang rekreatif yang } \\
\text { diterapkan pada } & \text { Solo Mega Sinepleks, } \\
\text { antara lain: } &
\end{array}
$$

- Menggunakan jenis massa tunggal dengan bentuk massa persegi yang digabungkan dengan bentuk lingkaran sebagai variasi.

- Karakter terbuka bangunan diwujudkan dengan penggunaan material kaca pada fasad dan area komunal pada bagian depan yang terbuka (lihat Gambar 6).

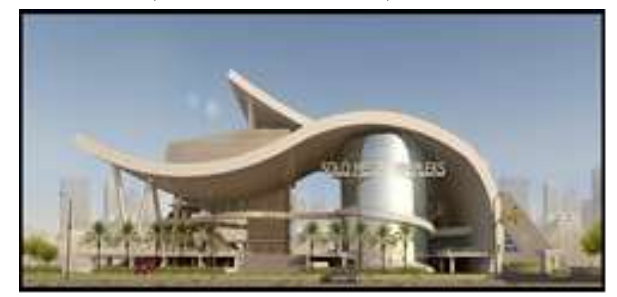

Gambar 6. Fasad Bangunan

- Mengatur jarak dan ketinggian massa bangunan untuk memaksimalkan potensi alami (matahari, angin dan lingkungan) ke dalam bangunan.

- Memperbanyak bukaan pada sisi timur dan meminimalisir bukaan pada sisi bagian barat (lihat Gambar 7)

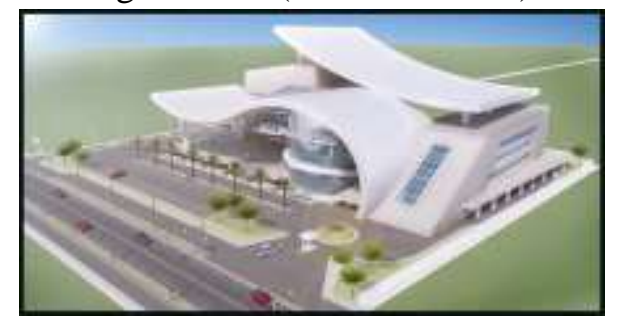

Gambar 7. Perspektif Eksterior

- Penggunaan dinding kaca dengan secondary skin untuk mengurangi efek panas yang ditimbulkan oleh cahaya matahari.

- Bentuk atap melengkung menyerupai roll film dan kemiringan atap yang menyerupai clapboard digunakan untuk menghasilkan tampilan 


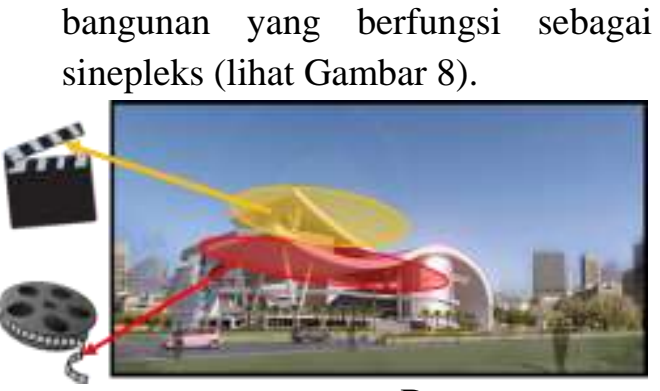

Gambar 8. Eksterior Bangunan

\section{REFERENSI}

Doelle, Leslie L. 1990. Akustik Lingkungan. Erlangga: Jakarta.

Suardana, I Nyoman Gde. Bali Post. Minggu 28 Agustus 2005. 